tonaceae the author finds evidence of reduction from "some form similar to the present submerged Potamogetons, with Zannichellia and Althenia serving as examples of still further reduction."

IN the Botanische Zeitung for November 1, 1908, H. Bruchmann's paper, "Das Prothallium von Lycopodium complanatum L." adds materially to our knowledge of the gametophyte generation of this species. The tissues of the erect, tuberous gametophyte are shown to consist of a rhizoid-bearing epidermis; a layer containing endophytes; a layer of radially arranged palisade cells, and a largecelled central mass of parenchyma. Branching occurs, giving rise to increased areas for the sexual organs. Some of these prothallia are unisexual and others bisexual. The sexual organs are crowded into dense masses at the summit of the prothallium and are of the usual type of structure.

AlBert ManN, expert in charge of special barley investigations in the Bureau of Plant Industry of the U. S. Department of Agriculture, makes a preliminary report of the results of his study of the problems of how to recognize the best grades of barley (Circular No. 16, issued November 25, 1908) in which he finds that "the diastatic and cytatic starch ferments are wholly the product of the scutellum and are secreted by its outer layer," and that there is so little of these ferments found in the starch cells that " it is practically negligible." Furthermore, "the aleuron layer has nothing whatever to do with this process," namely, the change of starch into a soluble form for absorption by the embryo, which is identical with what takes place in " malting." Hence the scutellum is the "malting organ," and that barley is best for malting purposes that contains the largest scutellum in the grain.

The University of Nebraska

Charles E. Bessey

SPECIAL ARTICLES

SOME GEOLOGICAL PROBLEMS

Among the larger problems in the geology of eastern North America which to-day claim attention are: the determination of the eastward and southeastward extension in their metamorphosed condition of the less altered rocks of the Hudson Valley and the satisfactory separation from these of the pre-Cambric; as well as the separation and correlation of the divisions of the latter, if such exist.

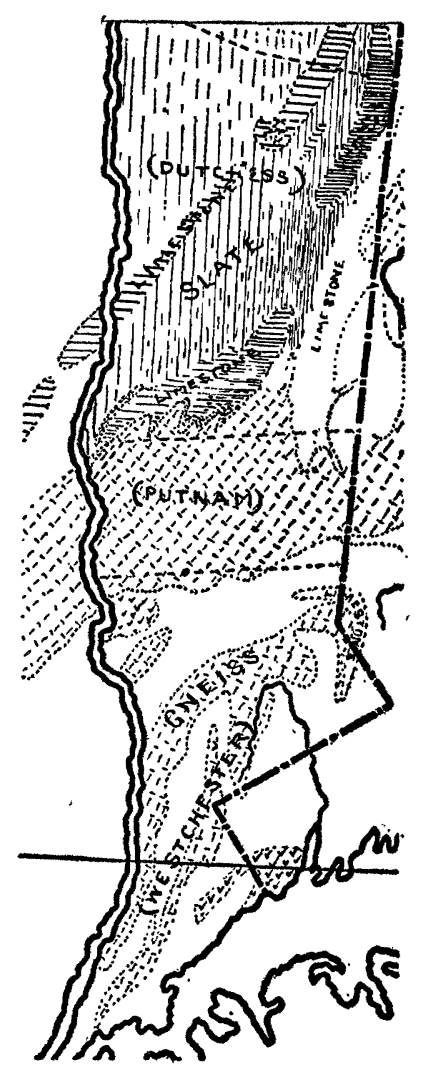

J. D. Dana early essayed to show the continuity of the limestones and schists of the New York-Connecticut border with those of Westchester County, New York. F. J. H. Merrill took up the question later and reached practically the same conclusions. The work of Cook in New Jersey had shown how intimately the lower Paleozoics are involved in the Highlands of that state. Many of the facts seemed to point to a oneness in age of much of this limestone, schist and slate with the unaltered rocks to the north and west in the Hudson Valley and on the flanks of the Highlands. 
The continuity of these rocks over large areas has been suggested and assumed rather than proved. Notwithstanding this they form a part of the same general problem, and any assumption regarding the age of one portion of this belt makes more imperative the need of better establishing the principles that will apply to the region as a whole. Any suggestion of incorrectness in age of any part raises the whole question to the fore.

Great uncertainty prevails in the minds of the Connecticut geologists as to the age of the greatly injected, disturbed and altered schists and limestones in the western part of that state. Manifestly any reasonable interrogation regarding the generally assumed age of the limestones and schists of southeastern New York is of great interest. The recent conservative suggestion of Berkey that the Inwood limestone and Manhattan schist are of pre-Cambric age is a case in point.

The work of Hitchcock and Emerson in Massachusetts, that of Percival, Dana and the Connecticut Survey in Connecticut, and that of Mather, Dana, Merrill and Berkey in New York has done much to unravel the complicated geology of this region; but much confessedly awaits solution. The problem is to a great extent a structural one and is complicated through metamorphism by igneous intrusion.

Limestones are known in the pre-Cambric rocks of Massachusetts, southeastern New York and New Jersey in the proximity of limestones of younger age. The uncertainty is not at this point, but as to which is which. The work of Cook, Britton, Nason and Bayley does not leave us clear as to what is assignable to the pre-Cambric and what to the Paleozoic in the Highlands of New Jersey. The New York geologists are working at this problem, and the New England geologists will doubtless take the subject up again in the near future.

Much doubtless depends upon the success we may attain in correlating areas with one another as well as in establishing principles that will fit them all, and to what extent such a thesis as may be drawn up can be supported by actual evidence, or reasonable inference, or both. With these general principles our interpretations of specific phenomena must fit if the principles are to stand.

The Geology of Dutchess County, New York. ${ }^{1}$

The study of these problems reasonably begins with the examination of the least altered strata of the Hudson Valley. These strata, showing continuously increasing metamorphism as they are traced eastward, are well displayed in Dutchess County. Field work in this county reveals that the metamorphism approaches the character of a function of the distance of the strata from the Hudson River. The increment by which the metamorphism approaches a given degree varies in value, but apparently always is greater per unit distance as one approaches the southern part of the county. The fact that the pre-Cambric rocks cut through the southeastern and southern portion of the county indicates that the degree of metamorphism may, in a measure, be directly connected with the proximity of the Highland mass.

The accompanying generalized sketch map is not intended to show the details of the areal geology of southeastern New York but rather to show pictorially the character of the general problem. It is based upon personal work in Dutchess County, particularly in the Poughkeepsie quadrangle, and upon the maps of Dana, Smock, Merrill and Berkey.

The north and south continuity of the western limestone belt (Barnegate or Wappinger) of Dutchess County was shown by W. B. Dwight. The identity of the eastern so-called Millerton-Fishkill belt with the Wappinger was proved for its northern or Millerton portion by the same worker. Recent work by the writer in the southern portion af the eastern belt, the Fishkill limestone, shows conclusively by the discoveries of fossils the presence of Georgian and Beekmantown terranes within this formation.

While considerably more metamorphosed than the Wappinger the alteration of the eastern limestone has not obliterated the

\footnotetext{
${ }^{1}$ Published with the consent of the New York State Geologist.
} 
evidence of its age. The identity of the northern and southern portions of this, belt is thus shown, and the eastward metamorphosed extension of the rocks of the Wappinger belt is likewise demonstrated. The intrarelationships of the western Wappinger are in some cases duplicated in part in the eastern belt. With these facts in mind the shading on the map is designed to show the gradation in metamorphism to the eastward.

To the east and south on the map are extensive areas of limestone and schist, for the most part left unmarked and unbounded, the satisfactory proof of the age of which awaits demonstration. Smaller patches not represented on the map, more intricately involved and often associated with igneous rocks, are scattered here and there in the Highlands. The great complex extends eastward into Connecticut, and southwestward into New Jersey, and has its representatives to the north in Vermont and Massachusetts. That it is a puzzling area is stating the case mildly. It must be attacked with a mind open for the reception of data bearing on the question of the possible genetic identity of extensive and disconnected masses or for the consideration of features that point the other way. The structure of the region must be unraveled and the earlier relationships of the component rocks restored. Moreover, it may be considdered an open question, if with the changes that the pre-Cambric rocks had early undergone, the later deformations and metamorphic agencies would not have produced a relatively greater alteration in the younger rocks.

It is purposed to discuss more fully certain features of the general problem in a forthcoming report on the geology of the Poughkeepsie quadrangle.

\section{E. GORDON}

AMHerst, MASs.

\section{THE AMERICAN ASSOCIATION FOR THE $A D V A N C E M E N T$ OF SCIENCE SECTION G-BOTANY}

Section $G$ of the American Association for the Advancement of Science met during convocation week at Baltimore, the sessions being held at the Eastern High School. The attendance of botanists was unusually large and representative, and so many papers were offered for presentation that it was found necessary to divide into subsections. In Subsection A were presented the papers in morphology, physiology, ecology and taxonomy, while the papers in pathology were presented in Subsection B. Vice-president Richards presided over Subsection A, and Dr. F. L. Stevens, of the North Carolina College of Agriculture and Mechanic Arts, was chosen by the section to preside over Subsection B. As at the Chicago meeting the program of the section interlocked with that of the Botanical Society of America, so that program conflicts were reduced to a minimum. The address of the retiring vice-president, Professor Charles E. Bessey, on "The Phyletic Idea in Taxonomy," has been published in full in ScIENce.

The following officers were chosen:

Vice-president-Professor D. P. Penhallow, McGill University, Montreal, Canada.

Member of the Council-Joseph N. Rose, U. S. National Museum, Washington, D. C.

Member of the Sectional Committee (five years) -Dr. D. T. MacDougal, Carnegie Institution, Tucson, Ariz.

Member of the General Committee-Professor Aven Nelson, University of Wyoming, Laramie, Wyo.

In view of the increasing difficulty of arranging the program in an equitable manner, the sectional committee appointed the retiring vice-president, Professor H. M. Richards, the incoming vice-president, Professor D. P. Penhallow, and the secretary, Dr. Henry C. Cowles, as a special program committee for the Boston meeting. In view of the coming meeting of the British Association at Winnipeg, the choice of a Canadian botanist for the vice-presidency of the section is regarded as most fortunate, and although no specific action was taken by the section at Baltimore, it was the general consensus of opinion that the American botanists should do all in their power to make the sojourn of the British botanists in America pleasant and profitable.

Abstracts of the technical papers presented at Baltimore follow, arranged in the order given in the respective subsections:

\section{SUBSECTION A}

Bog Toxins and their Effect upon Soils: ALFRED DAChNowski, Ohio State University, Columbus, Ohio.

In a previous communication (Bot. Gaz., 46: 130-143, 1908) attention was called to experi- 